\title{
IRAN AND SAUDI ARABIA IN THE MIDDLE EAST: LEADERSHIP AND SECTARIANISM (2011-2017)
}

\author{
Diansaei Behzad \\ RUDN University (Peoples’ Friendship University of Russia), \\ Moscow, Russia
}

\begin{abstract}
Relations between Iran and Saudi Arabia have never been at a desirable level. Iran's 1979 revolution, the fall of Saddam Hussein in Iraq and the Arab Spring in turn increased the disagreement between the two regional powers. This article examines the relationship between Iran and Saudi Arabia in the Middle East between 2011 and 2017. Both countries claim to have leadership over other Islamic Muslim countries in the Middle East, in which Iran as a Shia state and Saudi Arabia as a SunniWahhabi state have multiple ideological and political conflicts that have drawn opposing interests for each other.

As a result, new multifactor regional international situation involving Iran and Saudi Arabia arose, to analyze which it would make sense to apply the general scientific analytical methods (logical, typological, inductive-deductive methods, etc.), and a number of specific methods for direct study of international relations, including those based on a systemic approach.

The author examines the two powerful Middle Eastern countries with an emphasis on instrumental sectarianism as an important component of the regional order transformation process, understanding Iran as one of the superior powers of the region in the context of Islamic discourse and the same role of Saudi Arabia with strong tendency in the framework of Arab discourse. It was concluded that Iran and Saudi Arabia have ambitions for a larger share of the new Middle East and from the viewpoint of religious perspective, are instrumental in expanding their influence in the Middle Eastern countries.
\end{abstract}

Key words: Islamic Republic of Iran, Saudi Arabia, the Arab Spring, sectarianism, Middle East, Iranian-Saudi relations, superior powers of the region

The study of relations between Iran and Saudi Arabia as the largest country in the Arab part of the Persian Gulf region is dependent on relations between Iran and the Arabs in general. Meanwhile, due to the central role of Saudi Arabia in the Middle East, the Persian Gulf, and among Islamic countries, the type of Iran - Saudi relations has always been important in its peripheral environment. In other words, Saudi Arabia as one of the members of the Arab community has been always influenced by the events of the region and the types of interactions of each country of the Persian Gulf region, the Middle East and Iran. Creating a climate of trust and understanding or distrust and misunderstanding between the two countries has had positive or negative effects in the region and the Islamic countries. The victory of the Islamic revolution in 1979 and the formation of the Islamic Republic of Iran opened a new chapter in bilateral relations. After this victory the Shia revolutionary ideology was established in Iran which was in contrast with the Sunni-Wahhabi ideology of Saudi Arabia. In addition to the outbreak of the religious revolution in a monarchy kingdoms of the region, and Saudi Arabia as one of them, were aware of the possible danger of 
their own security. Particularly due to the thesis of the revolution these concerns were doubled. Policies and propaganda of the Western governments were used in kindling hostility and disagreements between Iran and Saudi Arabia [Borujerdi 2001: 145].

As a result, new multifactor regional international situation involving Iran and Saudi Arabia arose, to analyze which it would make sense to apply the general scientific analytical methods (logical, typological, structural systems, inductive-deductive methods, etc.), and a number of specific methods for direct study of international relations, including those based on a systemic approach. A systemic approach will enable a holistic analysis of relationships, forming multi-level system of international relations in the Middle East and between Iran and Saudi Arabia. Another objective of the study is to systematize conflicting assessments of the current situation in bilateral relations using for this purpose methodology of the theory of the international comparisons. An important task is a comprehensive study of various approaches in scientific literature to the study of the objectives and priorities of Iran and Saudi Arabia in the Middle East. Therefore in purpose to obtain the most relevant information on the scope of the research and on a perspective of the involvement of Iran and Saudi Arabia into political processes in the Middle East it is necessary to study a wide range of articles from scientific magazines, mass media, in particular, of the official sites of government departments and analytical centers. Thus the set of methods includes different analysis of sources and analytical materials, synthesis of information, comparison of data. Besides, in work the comparative analysis will be used. The current confrontation between Iran and Saudi Arabia has an important sectarian element, but it shouldn't be understood simply as a "Sunni versus Shia" confrontation. High regional dynamics of the playing a balance of power game should be taken into account then analyzing the role of sectarianism in that game in order the motives both Iran and Saudi Arabia not to be misunderstood.

The problem of studying the foreign policy of Iran and Saudi Arabia in the Middle East is an urgent task that deals with the growth of the Shia-Sunni confrontation. There is extensive literature on the impact of the events of the Arab Spring and the current operation to counter the forces of international terrorism in the region. However, the question of the analysis of the grounds for Saudi Arabia's and Iran's involvement in international relations in the Middle East, the problem of the influence of Islamic sectarianism on the transformation of the system of international relations and foreign policy of these leading countries of the region, as a rule, is not the focus of research. Without claiming to cover this topic in detail, we will give a brief overview of the main points of view on these issues, try to identify the main tasks that Iran and Saudi Arabia are solving in this context in the turbulent Middle East.

\section{THE ARAB SPRING AND SECTARIANISM IN THE MIDDLE EAST}

The Arab disorders has brought the situation in the Middle East into a new stage, called by some researches the "New New Middle East" or the "Third Arab Cold War" [Hinnebusch 2016]. Reshaping the Middle East the USA didn't assume that

\footnotetext{
1 "New" - modern, not historical; "new new" — after 2011.
} 
other realities will be imposed on their plans of updating of the region, therefore it is possible to accept the idea about "the New New Middle East". The political situation of the region in the post-instability period has been the process that began in the 2000 's and led to the polarization of the Middle East. International relations in the region after the events of 2011 can be seen with an intensification of sectarian gaps (between Shia and Sunni Muslims) and an increase in the role of non-state actors. In general, the role of transnational identities in the Middle East in the discussed period is an indicator of the existing weakness of the state institution. Within this framework, religious sectarianism has become a political tool for regional hegemons, in addition to relation to affiliated groups in the countries with deep ethnic-sectarian gaps, they have also influenced balance of power [Shaw 2009].

An instrumentalized sectarianism ${ }^{2}$ as a component of regional order is a new phenomenon that has been accelerated by the U.S. intervention during the regional power struggle. But the Islamic sectarianism long pre-existed the American invasions [Rosen 2010]. On one hand, the 2010-2011 Arab Spring intensified the power struggles in the Middle East, and on the other hand, led to a bigger sectarianism instrumentation of the regional states. In other words, the presence of jihadists in the countries experiencing uprisings due to sectarian sensitivities has led to an unprecedented spread of transnationalization of sectarian movements [Narbone, Lestra 2015]. In addition, security concerns led to the proximity of the parties involved to the relevant social groups, and this combination along with ethnic cleansing and the domination of sectarian discourse on television and social media intensified sectarianism in the Middle East after the period of uprisings. Therefore, the role of transnational Arab and Islamic identities in the sectarian format continues to be their state form through Iran and Saudi Arabia [Khoury 2013]. The main lines of this state are defined by also legal ground - the Ja'fari School in Iran and the Hanbali school in Saudi Arabia.

During the process of sectarianism in the Middle East powerful states use different strategies. Saudi Arabia which plays a key role in Sunni sectarianism has introduced the Shias as a pagan minority and emphasized the role of Iran as a non-Arab actor in the Arab world seeking to exploit the majority of the Sunni world against $\mathrm{Iran}^{3}$. Contrary to that, the Islamic ideology discourse of Iran aims at rebuilding

${ }^{2}$ Instrumentalized sectarianism - "The first step toward sectarianization is the politicization of sectarian differences for instrumental ends: political entrepreneurs are incentivized to instrumentalize sectarianism to mobilize sects in intra-state competition over resources, as famously in Lebanon, and individuals to use sectarianism to gain access to clientele networks. This 'instrumental sectarianism' has little doctrinal implications or necessary incompatibility with sectarian coexistence... instrumental sectarianism facilitates defensive collective action (e.g. the minorities in the Syrian civil war). Militant sectarianism — in the Muslim world jihadism — has an intense normative content, seeks to impose (universalize), if need be by force, a one true interpretation of religion - usually a fundamentalist one - in the public sphere; it demonizes those who do not comply as infidels and often embraces martyrdom for the cause" [Hinnebusch 2016: 123].

${ }^{3}$ Kalin, I. (2014). Sectarianism: A Recipe for Disaster for Sunnis and Shiites. URL: https://www.dailysabah.com/columns/ibrahim-kalin/2014/06/17/sectarianism-a-recipe-for-disaster-forsunnis-and-shiites (accessed: 07.03.2016). 
Muslim resistance against the United States and Israel and their regional partners (led by Saudi Arabia). In contrast, Saudi Arabia uses Salafi elements, and the Islamic Republic of Iran relies on the mobilization of the transnational network of Shia minorities [Gause 2014].

Regarding the global affairs, the Islamic Republic of Iran national security strategy "has been premised on the belief that resisting U.S. hegemonic aspirations in the Middle East is not only the source of Iran's strength, but allows it to maintain its independence". On the contrary, Saudi Arabia "views the United States as its security guarantor and has relied on U.S. military, political, and economic patronage for decades. In May [2017 — note by the author], MBS signaled his aim to continue this dependency by signing the largest arms deal in U.S. history for $\$ 350$ billion - and thereby winning full support for his regional and domestic agenda from the White House" 4 .

\section{POSITIONS AND POLITICS OF SAUDI ARABIA}

In general, the regional status of Saudi Arabia was in an unfavorable situation due to overthrowing Saddam Hussein in Iraq in the 2000's and its position during the 2006 Israel-Hezbollah War (the July war). The negative results of the Arab uprisings have led to the collapse of the authoritarianism and have changed the regional balance more favorably for the rivals. In this regard, Saudi Arabia which throughout the history of the new Middle East has always been one of the main actors and leader of the ArabIslamic world for a considerable number of Arab countries, have formed a bloc of power together with other monarchies of the Cooperation Council for the Arab States of the Gulf (GCC). The goal of such policy was to confront the wave of uprisings in the member states and then promote their regional status [Gause 2011].

In the following section, there is a summary on relations of some of the countries that have experienced Arab uprisings (Libya, Syria) and Saudi Arabia in the frames of the Alliance.

The Libyan government during the presidency of Muammar Gaddafi was selling weapons to Iran during the Iran-Iraq war as a part of balancing policies (1988-1989). His adventurous actions such as the assassination of King Abdullah, former king of Saudi Arabia, the disregard for the Arab League decisions, etc. for most of Arab states in the region, the Middle East and North Africa has always been considered as those of an enemy and an undesirable element. Therefore, the uprisings in this country were an opportunity for the regional governments and particularly the members of the Holy Arab Alliance, to get rid of Gaddafi. In this regard, after the uprisings in this country and Gaddafi losing control of the parts of the country Saudi Arabia and other monarchies used the mass media (Al Jazeera and Al Arabiya) and influence of their voices in the Alliance to stand against Libya [Filipkova, Hesova, Karasek, Kubikova, Kuzvart, Zahora 2012].

\footnotetext{
${ }^{4}$ Mousavian, H.S. (2018). Contrasting Leadership Styles in the Saudi-Iran Conflict. URL: http://lobelog.com/contrasting-leadership-styles-in-the-saudi-iran-conflict/ (accessed: 05.01.2018).
} 
In this period Syria has become an important part of the Saudi Arabia regional strategy; the uprisings in such cities as Daraa, Hama and Homs were a chance for this country to change negative response of Syria not to be represented in the opposition to join the American peace block and reduce the level of its relations with Iran [O’Bagy 2013].

The given description represents the general policies of Saudi Arabia within the Holy Arab Alliance in the Middle East after the uprisings. This policy was formed in January 2005. In this regard, the new government of Saudi Arabia had cooperation within the framework of the Gulf Cooperation Council.

In this context Saudi Arabia knowing the importance of the role of identities in the Middle East, mainly Sunnis, Sunni-Arabs tried to limit sectarianism in the area of Iran's influence. This country considers all the Arab lands as its potential sphere of influence and thinks that Iran's proximity to the Shia Iraqi government or Hezbollah powerful organization in Lebanon as not unacceptable. In this regard, the Saudis pursued their activities at both regional and national levels to regulate influence of Iran.

In order for Saudi Arabia to change regional equilibrium and reduce the role of Iran, they expect the U.S. to support three countries: Iraq, Syria and Yemen. In Iraq, the Saudi government wants a comprehensive government that is less focused on Shia sectarian tendencies. The Saudis know that most part of the Iraqi population is Shias. Accordingly, there is no possibility of transferring power to the Sunnis, but the existence of a state with less sectarian tendencies can reduce influence of Iran as the largest Shia state in the region. On the contrary, since the majority of Syria's population is Sunnis the Saudis are seeking to overthrow the rule of al-Assad and transfer power to other party. In this regard, the strategy of removing Syria from the Iranian influence would disconnect Iran and Hezbollah from Lebanon. Eventually, the Houthis' defeat in Yemen and the transfer of power to Abdrabbuh Mansur Hadi were Saudi Arabia's last steps aimed at overcoming the risk of regional influence in Iran. On the one hand, the Saudi politicians wanted to strengthen the military power of this country with the help of the U.S., and on the other, not to let the presence of Iran in other Arab country of the Middle East ${ }^{5}$.

\section{YEMEN BETWEEN SAUDI ARABIA AND IRAN}

Yemen like most of the other Arab states, faced uprisings in 2011-2012. Yemen is one of the other countries that, in the light of Arab uprisings, was the scene of Saudi and Iran involvement.

At the regional level, attack of Saudi Arabia on Yemen aimed at suppressing its Shia minority is in fact a reaction to the regional role of Iran. This is followed by the widespread mobilizing of opponents of Bashar al-Assad and especially the Islamists who were active in the Syrian civil war. At the national level, Saudi Arabia recently aimed at violating internal security of Iran. So, the relations between the former and current

5 Althunayyan, H. (2017). The U.S.-Saudi relations in the Trump era. Aljazeera Media Network. URL: http://www.aljazeera.com/indepth/opinion/2017/05/saudi-relations-trump-era-170518084540044.html (accessed: 02.11.2017). 
officials of the country with Iranian opposition groups abroad (Kurdish separatists and the People's mujahidin organization of Iran) were the reason of decisive solutions of Saudi Arabia and its allies in the region to limit $\operatorname{Iran}^{6}$. Barack Obama as the strategic partner of Saudi Arabia in the region was also cautious against the U.S. involvement in so called "proxy wars" fueled by Saudi-Iranian competition in the Middle East as, for example, in Yemen and Syria [Schmierer, Jeffrey, Nader, Nazer 2016].

During the period of the spread of uprisings and the transfer of power in the country, intervention of Iran in Yemen and its support for the Zaidi Shia minority were never discussed. But this matter was mentioned by members of the GCC after the Houthis dominated Sana'a and the disengagement of the President approved by Saudi Arabia in 2014. Despite Iran's support for the activities of Islamic movements and in particular the Shias in the region, the Houthis' actions were also surprising to Iran [Esfandiary, Tabatabai 2016].

On this basis, due to the weakness of civil society, the existence of ideological gaps along with the activities of radical Islamist groups has led to the government's severe inability to resist in Yemen. In this regard, major concern of Saudi Arabia as a neighbor of Yemen was to stabilize the country and prevent the spread of uprisings in Saudi Arabia [Matthiesen 2015]. Following the spread of uncertainties and split between the army and the central government in Yemen, the Saudi government in pursuit of its historic role in this country sought to secure security concerns. In this regard, plan of the Gulf Cooperation Council supported by the U.S. and European Union provided mediation for the peaceful transfer of power from Ali Abdullah Saleh, president of Yemen during the uprisings, to Abdrabbuh Mansur Hadi who was launched in 2012 [Thiel 2012].

Later it included such operations as "Decisive storm", "Restoring hope" on March 25, 2015 in Yemen, following the goal of limiting Shia Houthis on political arena of this country. It seems that such an offensive policy of Saudi Arabia and its allies was a reaction to US regional policy under the presidency of Barack Obama (2009-2017) and their support of Arab monarchies and ineffectiveness of the above-mentioned countries under the governance of Saudi Arabia in preventing conclusion a nuclear deal between Iran and the P5+1 (China, France, Russia, the United Kingdom, and the United States, plus Germany). Iran's withdrawal from international isolation by nuclear resolutions would increase its ability to engage in regional conflicts. Based on this, the regional changes have created the feeling that only the Arab states, especially Saudi Arabia unlike in the past had to play their regional role alone and balanced the position of Iran [Gause 2015].

The coincidence of the successes of Houthis in Yemen, the presence of the Quds Force in Iraq and Syria sparked the feeling that the country was seeking expansionist policies in the region. Yet, unlike Yemen, Iraq, Syria and Lebanon have a much higher position in the vast orientation of Iran's foreign policy. Despite the support of Iran for Shias and particularly the Ansar Allah group in Yemen, the lack of response of this

${ }^{6}$ Karami, A. (2016). Saudi Prince's endorsement of MEK angers Iranian officials. AL-Monitor. URL: http://www.al-monitor.com/pulse/originals/2016/07/iran-mek-mojahedin-saudi-turki-bin-faisal.html (accessed: 10.09.2017). 
country to airstrikes of Saudi Arabia and the Arab coalition shows a lack of understanding of position of Yemen in the foreign policy of Saudi Arabia and to this point draws attention to Iranian politicians [Mohseni 2015]. In the case of Yemen statements of the Iranian authorities and their position showed the Iranian government did not want to oppose Saudi Arabia.

\section{POSITIONS AND POLITICS OF THE ISLAMIC REPUBLIC OF IRAN}

Before the beginning of Arab uprisings, the Islamic Republic of Iran as the leader of the resistance block in the Middle East was in a better position than other major regional actors. After the overthrow of Taliban in Afghanistan (2001), Saddam Hussein in Iraq (2003) for the first time after the Islamic Revolution Iran was able to appear as a major regional actor, support Hezbollah in 2006 Lebanon War (the July war), and with some support of the Arab Middle Eastern societies increase its soft power in the region. Iran and Syria enjoyed the Syrian-Iranian strategic partnership or axis [Goodarzi 2013]. In this regard, the decade before the Arab uprisings was the period of the growth and consolidation of regional power of Iran in the Middle East due to its success in Syria, Lebanon, Iraq, and Palestine. In the beginning the Iranian government viewed uprisings in the Arab countries with some skepticism and it also "felt threatened by the possibility that the reformists inside Iran would be inspired by them, and try to reproduce the experience in their own country" [Firas 2011: 4]. Also "both the conservative elements who support Ahmadinejad and those who support Khamenei — viewed the Arab revolts through the prism of Iran's foreign relations and regional alliances. It forms a plank of their policies to have Iran firmly ensconced as a major regional power, one which promotes Shia power throughout the world" [Firas 2011: 10]. Within the framework of the Iranian fundamentalist discourse it was interpreted as a natural continuation of the "Islamic Awakening" of the Iranian people and the Iranian Islamic revolution. As it was mentioned "Khamenei expressed this in a speech in Tehran at an international conference on Islamic Awakening, held in 2011... This position led to deep disagreement between the Islamic Republic and the Muslim Brotherhood in Egypt" [Al-Smadi 2017].

The rapid collapse of the secular and supported by the United States regimes in Egypt and Tunisia as well as the high role of Islamic movements in overthrowing these regimes have changed the attitude of Iranian authorities towards recent changed in the region, so that they interpreted these uprisings as the continuation of the Islamic Revolution of Iran and referred to it as "Islamic Awakening" [Kurzman 2012].

If the Arab uprisings are considered to be only a series of revolutions, it is the product of the rivalry between the two main actors in the Middle East region - Iran and Saudi Arabia. In turn, "that it is the result of the Shia-Sunni divide. The divide is a driver of Saudi and Iranian foreign policies, but the key motive for both countries is to preserve the security of the state" [Keynoush 2016]. Meanwhile, Bahrain and Yemen were the main battlegrounds between the powers in terms of neighboring Saudi Arabia and the considerable number of Shias.

Regarding the uprisings in Bahrain where more than 70 percent are Shias and the country is under control of the Sunni minority, the Iranian government is primarily 
concerned of the intervention of Saudi Arabia and the UAE armies along with other Arab (Jordan) and even the non-Arab countries (Pakistan) in the region under the guidance of the security forces of the GCC who severely suppressed the peaceful political protests [Ulrichsen 2015]. In relation to this, members of the Holy Arab Alliance condemned Iran in interfering in the international affairs of their countries [Mabon 2012]. The geographical proximity of Bahrain to the Eastern Province (Al-Sharqiyyah) and in particular the cities of Dammam, Al-Ahsa and Qatif where the biggest amount of Shias in the country live, as well as the geopolitical significance of the area for the Saudis in terms of the presence of major Saudi oil supplies near it is a matter of concern for Saudi Arabia and other countries of the Holy Arab Alliance. It was explained by a possible takeover of power by the Bahraini Shias, which could change the regional equilibrium and Iran's further expansion of regional influence over the last decade. Therefore, with the knowledge of the role and position of supra-national identities in the region these countries are trying to control the opposition.

Unlike Bahrain and Yemen, Egypt had a great importance in the regional strategy of Iran after the presidency of Hosni Mubarak.

First of all, it was due to its geopolitical position in the Arab world close to Israel. In this regard, the Iranian government in the short period of Muslim Brotherhood (the Society of the Muslim Brothers) being a political power, wanted Egypt to establish friendly relations with the country [El-Labbad 2014]. In fact, there was no possibility to establish friendly relations between the two countries due to such factors as strong economic dependence of Egypt on the U.S. and the Persian Gulf monarchies, opposition of the Syrian Muslim Brotherhood to the rule of Bashar al-Assad, Iranian support of Morsi until the military coup d'état in July 2013. Thus, overthrow of Morsi's government has never led to a deep-seated friendly relationship between the two countries [Hinnebusch 2014].

According to particularly Article 154 of the Constitution of the Islamic Republic of Iran, "the Islamic Republic of Iran has as its ideal human felicity throughout human society, and considers the attainment of independence, freedom, and rule of justice and truth to be the right of all people of the world. Accordingly, while scrupulously refraining from all forms of interference in the internal affairs of other nations, it supports the just struggles of the freedom fighters against the oppressors in every corner of the globe" 7 . Therefore, the interference in other country's affairs is not acceptable until it is the oppressed people. That explains the overall orientation of the foreign policy of this country where there is no doubt that defending the Palestinian Muslim nation against Israel will be Iran's Government civic duty and one of the highest priority in international politics. In this regard, view of Iran on the uprisings in Syria is more focused on the country's position as the only state actor along with Iran in the resistance axis, so that the axis is currently the only bloc of unified power against Israel in the region. Therefore, Iran aims to adopt a sing united policy of the regional countries towards Israel. For Iran, helping to maintain secular rule of Bashar al-Assad is important because it has a con-

${ }^{7}$ Constitution of the Islamic Republic of Iran. Adopted on: 24 October 1979. Amended on: 28 July 1989. URL: http://en.mfa.ir/uploads/Constitution_8032.pdf (accessed: 21.12.2017). 
nection role of Iran and Hezbollah in Lebanon. On the other hand, the two countries are sharing their stance on hostility to Israel [Malt Zahn 2015].

As one of the superior powers of the region, Iran like other key actors wants to play a regional role, but this role is defined in the context of Islamic discourse. Just as Saudi Arabia today has this tendency in the framework of Arabic discourse ${ }^{8}$. It should be noted that until the writing of the present study Syria stays a blind spot of the regional play between Iran and other countries of the Middle East.

$* * *$

In conclusion, dealing with Iran's relations with Saudi Arabia in the Middle East crisis and the creation of the new Middle East from 2011-2017 it must be stressed that Iran and Saudi Arabia, from the viewpoint of religious perspective, are instrumental in expanding their influence in the Middle East and its countries. They have ambitions for a larger share of the renewed Middle East. Therefore, hope for peace in the Middle East region is impossible to imagine as reality in the near future. And the two countries will deal with this confessional sentimental means of putting the Sunni coalition against the Shia coalition to confront each other in the Middle East.

\section{REFERENCES}

Al-Smadi, Fatima. (2017). Iran and the Arab Revolutions: Narratives Establishing Iran's Monopolism. 18 March 2017. URL: http://studies.aljazeera.net/en/reports/2017/03/iran-arab-revolutionsnarratives-establishing-irans-monopolism-170318050125225.html (accessed: 22.12.2017).

Borujerdi, A.H. (2016). Development of Arab-Iranian relations. Tehran: Publishing house of Ministry of Foreign Affairs.

El-Labbad, M. (2014). Egypt: A Regional Reference in the Middle East. In: Regional Powers in the Middle East: New Constellations after the Arab Revolts. Ed. by H. Furtig. New York: Palgrave, p. $81-91$.

Esfandiary, D. \& Tabatabai, A. (2016). Yemen: An Opportunity for Iran-Saudi Dialogue? The Washington Quarterly, 39 (2), 155-174. DOI: https://doi.org/10.1080/0163660X.2016.1204415.

Filipkova, L., Hesova, Z., Karasek, T., Kubikova, N., Kuzvart, J. \& Zahora, J. (2012). NATO and the Arab Spring: challenge to cooperation, Opportunity for Action? Association for International Affairs. URL: https://www.amo.cz/wp-content/uploads/2015/11/pp-2012-01.pdf (accessed: 10.09.2017).

Firas, Abu Hilal. (2011). Iran and the Arab Revolutions: positions and Repercussions. Arab Center for Research and Policy Studies. Doha. URL: https://www.dohainstitute.org/en/lists/ACRPSPDFDocumentLibrary/Iran_and_the_Arab_Revolutions_Positions_and_Repercussions.pdf (accessed: 04.04.2016).

Gause, G. (2011). Is Saudi Arabia really counter-revolutionary? The Middle East channel. Foreign policy. URL: http://foreignpolicy.com/2011/08/09/is-saudi-arabia-really-counter-revolutionary/ (accessed: 16.03.2017).

Gause, G.F. (2014). Beyond Sectarianism: The New Middle East Cold War. Brookings Doha Center. URL: https://www.brookings.edu/wp-content/uploads/2016/06/English-PDF-1.pdf (accessed: 12.03.2017).

${ }^{8}$ Khalid, A. (2011). Iran calls on Syrian President to consider protesters demands. Independent. URL: http://www.independent.co.uk/news/world/middle-east/iran-calls-on-syrian-president-toconsider-protesters-demands-2345536.html (accessed: 12.07.2016). 
Gause, G. (2015). The Future of U.S - Saudi Relations: The Kingdom and the Power. Foreign Affairs, 95(4). URL: https://www.foreignaffairs.com/articles/united-states/2016-06-13/future-us-saudirelations (accessed: 16.03.2017).

Goodarzi, J.M. (2013). Syria and Iran: Alliance Cooperation in a Changing Regional Environment. Middle East Studies, 4 (2), 31-59.

Hinnebusch, R. (2014). The Arab Uprisings and The MENA Regional States System. Uluslararasi iliskiler-International relations, 11(42), 7-27.

Hinnebusch, R.A. (2016). The Sectarian Revolution in the Middle East. R/Evolutions: Global Trends \& Regional Issues, 4(1), 120-152.

Keynoush, Banafshe. (2016). Saudi Arabia and Iran: Friends or Foes? London: Pallgrave and Macmillan.

Khoury, N.A. (2013). The Arab Cold War Revisited: The Regional Impact of the Arab Uprising. Middle East Policy, 20 (2), 73 - 87.

Kurzman, C. (2012). The Arab Spring: Ideals of the Iranian Green Movement, Methods of the Iranian Revolution. International Journal of Middle East Studies, 44(1), 162-165. DOI: https://doi.org/ $10.1017 / \mathrm{S} 0020743811001346$.

Mabon, S. (2012). The Battle for Bahrain: Iranian-Saudi Rivalry. East Policy, 19(2), 84—97. DOI: 10.1111/j.1475-4967.2012.00537.x.

Malt Zahn, N.V. (2015). The Syria-Iran Axis: Cultural Diplomacy and International Relations in the Middle East (Library of Modern Middle East Studies). London, New York: I.B. Tauris \& Co Ltd.

Matthiesen, T. (2015). Transnational Identities after the Arab Uprising. In: The Gulf Monarchies beyond the Arab spring: changes and challenges. Ed. by L. Narbone \& M. Lestra. Florence: European University Institute, p. 32-36. DOI: 10.2870/930212.

Mohseni, P. (2015). Iran and the Arab World after the Nuclear Deal: Rivalry and Engagement in a New Era. Belfer Center for Science and International Affairs. URL: https://www.belfercenter.org/ sites/default/files/legacy/files/Impact\%20on\%20Arab\%20World\%20-\%20Web.pdf (accessed: 22.08.2017).

Narbone, L. \& Lestra, M. (2015). The Gulf Monarchies beyond the Arab spring: changes and challenges. Florence: European University Institute. DOI: 10.2870/930212 URL: http://cadmus.eui.eu/ handle/1814/37734 (accessed: 12.08. 2016).

O'Bagy, E. (2013). The free Syrian Army. Institute for the Study of War. URL: http://www.understandingwar.org/report/free-syrian-army (accessed: 06.09. 2017).

Rosen, N. (2010). Aftermath. Following the Bloodshed of America's wars in the Middle East. N.Y.: Nation books.

Schmierer, R., Jeffrey, J. F., Nader, A. \& Nazer, F. (2016). The Saudi-Iranian Rivalry and the Obama Doctrine. Middle East policy, 23(2), 5-30.

Shaw, M. (2009). Sociological approaches to international relations. URL: https://www.eolss.net/ sample-chapters/C14/E1-35-01-07.pdf (accessed: 12.08. 2016).

Thiel, T. (2012). After the Arab Spring power shift in Middle East? Yemen's Arab Spring: from youth revolution to fragile political transition. LSE Research Online. London School of Economics and Political Science. URL: http://eprints.lse.ac.uk/43465/1/After\%20the\%20Arab\% 20Spring_Yemen\%E2\%80\%99s\%20Arab\%20Spring\%281sero\%29.pdf (accessed: 02.09.2017).

Ulrichsen, K.C. (2015). The Uprising in Bahrain: Regional Dimensions and International Consequences. In: Routledge Handbook of the Arab Spring: Rethinking Democratization. Ed. by Labra Sadiki. New York: Routledge Taylor \& Francis Group, p. 133-144.

Received: 1.12 .2017

For citations: Diansaei, Behzad (2018). Iran and Saudi Arabia in the Middle East: leadership and sectarianism (2011-2017). Vestnik RUDN. International Relations, 18(1), 124-134. DOI: 10.22363/2313-0660-2018-18-1-124-134. 
About the author: Diansaei Behzad — postgraduate student of the Department of Theory and History of International Relations of the RUDN University (e-mail: behzaddiansaee@gmail.com).

DOI: $10.22363 / 2313-0660-2018-18-1-124-134$

\title{
ИРАН И САУДОВСКАЯ АРАВИЯ НА БЛИЖНЕМ ВОСТОКЕ: ЛИДЕРСТВО И МЕЖРЕЛИГИОЗНАЯ КОНФЛИКТНОСТЬ (2011-2017)
}

\author{
Диансаи Безад \\ Российский университет дружбы народов, \\ Москва, Российская Федерация
}

Отношения между Ираном и Саудовской Аравией всегда были далеки от идеальных. Революция 1979 г. в Иране, падение режима Саддама Хусейна в Ираке и арабская весна привели к еще большим разногласиям между этими региональными державами. В статье анализируются отношения Ирана и Саудовской Аравии на Ближнем Востоке в период с 2011 по 2017 г. Обе страны претендуют на лидерство среди мусульманских стран Ближневосточного региона, в котором шиитское государство - Иран и суннито-ваххабитское государство - Саудовская Аравия преследуют противоположные интересы, участвуя в многочисленных идеологических и политических конфликтах.

В результате в регионе сформировалась сложная многофакторная ситуация с участием Ирана и Саудовской Аравии, для анализа которой автором были использованы общенаучные аналитические методы: логические, типологические, индуктивно-дедуктивные методы, а также системный подход. Особое внимание автор уделяет фактору межрелигиозной конфликтности как важному инструменту в процессе трансформации регионального порядка, анализируя деятельность основных акторов в рамках исламского дискурса в регионе - Ирана и Саудовской Аравии, усиливающей свои позиции также и в рамках арабского дискурса.

Сделан вывод о том, что Иран и Саудовская Аравия желают увеличить свою долю на Ближнем Востоке и, говоря о религиозной перспективе, готовы к расширению своего влияния в ближневосточных странах.

Ключевые слова: Исламская Республика Иран, Саудовская Аравия, арабская весна, сектантство, Ближний Восток, ирано-саудовские отношения, региональные лидеры

Дата поступления статьи: 1.12.2017

Для цитирования: Diansaei Behzad. Iran and Saudi Arabia in the Middle East: leadership and sectarianism (2011 - 2017) // Вестник Российского университета дружбы народов. Серия: Международные отношения. 2018. Т. 18. № 1. С. 124-134. DOI: 10.22363/2313-0660-2018-18-1124-134.

Сведения об авторе: Диансаи Безад - аспирант кафедры теории и истории международных отношений Российского университета дружбы народов (e-mail: behzaddiansaee@gmail.com)

(C) Diansaei Behzad, 2018 